\title{
Analyzing post-socialist grassland conversion in a traditional agricultural landscape - case study Croatia
}

\section{This paper was published in Journal of Rural Studies,}

\section{doi:10.1016/j.jrurstud.2017.01.008}

\begin{abstract}
Shrub encroachment and agricultural intensification have been a widespread occurrence in the former communist and socialist countries of Central and Eastern Europe. Such changes have strongly affected grassland areas which are seen as hotspots of biodiversity in Europe. In this study we have investigated the changes in grassland cover as well as the causal mechanism of those changes in a selected region in Northern Croatia during the post-socialist transition. By using the mixed methods approach we combined remote sensing, statistical modelling and a household-based questionnaire $(n=285)$ to map the changes in the grassland cover and to assess the socio-economic and bio-physical contributing factors of the documented changes. The results demonstrate that areas seeing general depopulation trends and population ageing, along with increases in the amount of educated people are characterized by shrub encroachment and farmland abandonment, while flatlands and lowland areas are seeing higher rates of grassland to farmland conversion. The results also show that the partial de-agrarization characteristic for the socialist period has become a full de-agrarization in the post-socialist period, with the main impetus being education, rather than employment, as was the case during socialism.
\end{abstract}

Keywords: post-socialism, grasslands, Croatia, mixed-method; land cover change

- We analysed the drivers of grassland change in the post-socialist period

- Socio-economic changes during economic transition have affected livelihood strategies

- Grasslands have lost their function due to disappearance of pasturing practices

- Traditional values still play an important role in preserving landscape characteristics 


\section{INTRODUCTION}

Agricultural landscapes have been changing rapidly in Europe in the last 50 years as a consequence of different environmental, demographic, economic and political trends. The two most common processes of change in agricultural land use are the abandonment of traditionally managed farmland and the acquisition of a modern regime of agricultural management (Gerard et al. 2010; Osawa et al. 2013; Regos et al. 2015, Caravelli 2000; MacDonald et al. 2000). The consequence of both has been the dramatic reduction of grassland areas in many parts of Europe. Grassland areas have either been transformed into arable fields due to intensification, or, as part of the process of abandoning grazing and mowing, they are increasingly being encroached upon by shrubs and forests (Hellessen and Levin 2014; Meshinev et al. 2000; Vassilev et al. 2011, Tasser et al., 2007). Evidence of this has been documented in parts of the Iberian Peninsula, the Alps, and along the Mediterranean, as well as some areas of Northern, Central and Eastern Europe (Diogo and Koomen 2012; Maestre et al. 2009; Komac et al. 2013; Biro et al. 2013; Rutherford et al. 2007; Zimmerman et al. 2010; Vigl et al. 2016).

A positive impact from such changes in land use and land cover can be seen in relation to forest succession - declines in fragmentation of habitats and increases in undisturbed habitats (Pazur et al. 2014; Kuemmerle et al. 2010), reduced erosion (Renwick et al. 2013) or mitigating climate change through increased carbon sequestration (Silver et al. 2000). However, the preservation of grassland areas is crucial to biodiversity in agricultural landscapes. An estimated $50 \%$ of all species in Europe depend on extensively managed habitats such as grasslands (Helessen and Levin 2014). Moreover, the increased rates of shrub encroachment which are a direct result of agricultural abandonment, lead to an increased risk of fire (Pavlek et al. in press; Nunes et al., 2005; Martinez et al., 2009) as well as changes in 
the landscape and potential loss of its cultural-historic values (Barankova et al. 2011, Shucksmit and Rønningen, 2011).

The rates of land use change observed in the former socialist countries of Eastern and Central Europe have been especially high (Pazur et al. 2014; Müller et al. 2013; Cvitanović et al. 2016, Lieskovský et al. 2015; Václavik and Rogan 2009; Taff et al. 2009; Baumann et al. 2011; Skokanová et al. 2016). The rapid political changes which took place in these countries have completely transformed their economic policies and markets. The process of restitution of nationalised properties was started, and a number of obsolete industries collapsed, resulting in increased unemployment. The restitution of properties along with the reduction of state interference and input into agriculture left its mark on both the structure and size of agricultural properties which in turn influenced land use outcomes, resulting in large tracts of land being abandoned in a relatively short period of time (Müller et al. 2013; Lerman 2001).

Political driving forces had an important role in those processes, i.e. the aforementioned withdrawal of the state from the agricultural sector and the individualisation of land use. There are, however, notable exceptions to this process. After the end of the Second World War the communist government of Yugoslavia had several attempts at collectivization, but the practice of collectivism was abandoned by the end of the 1950 s and between $81 \%$ and $89 \%$ of agricultural land ended up back in private hands (Bićanić 2010; Orazem, 1989). Thus, since 1950s the organization of Yugoslav agriculture has been bimodal, consisting of a socialist sector and private farming sector. Socialised agricultural enterprises encompassed less than $20 \%$ of land but had access to agro-technical services and agricultural subsidies, used nearly $40 \%$ of the total amount of mineral fertilizer and significantly contributed to production of wheat, rye, barley, corn and oats for the Yugoslavian market. On the other hand, private subsistence farms were mostly focused on household needs rather than to the market. They also received subsidies, but only under special circumstances and on a much 
lower level (Orazem 1989). Furthermore, farmers with farms close to agricultural maximum in size (10 ha) were precluded by law from purchasing or leasing smaller holdings which could make the use of modern technology more economical (Orazem 1989).

Such policies resulted in the decay of the Yugoslavian agricultural sector. Rapid industrialization was favoured over agricultural development, which resulted in massive emigration from rural to urban areas, causing a sharp decrease in agricultural employment (Allcock 2000; Lukić 2012). This trend of rapid decrease of agricultural population continued in the following decades. The land itself, however, was not abandoned to a large extent. Persisting difficulties in providing adequate urban housing made it impossible for the people working their new urban jobs to completely abandon their rural residences. These so-called "peasant-workers" undertook commutes from rural areas to urban centres (Allcock 2000; Vresk 1972). This provided the foundation for sustaining the small land-owner structure and a traditional agricultural landscape created through the reforms after the Second World War. An important role in maintaining the relative stability patterns of land holding over the entire socialist period was played by the development of tourism which took off in the 1970s, especially in Croatia, one of the six constituent republics of Yugoslavia. The impact of emigrant remittances is not to be discounted either. The 1980s saw more than a million privately owned estates smaller than 2 hectares with an additional 1.3 million in the 2-10 hectare category. The mixed pattern of private agricultural management is also apparent from the fact that in 1981 only around $25 \%$ of Croatian households made a living solely from their agricultural income, and only $25 \%$ made their living solely from their non-agricultural income (Allcock 2000). However, although limited, research dealing with agricultural abandonment in Croatia during socialism has shown an increase in grassland areas in latter periods of socialism, mostly due to previously mentioned processes of de-agrarization, de-ruralization and subsequent migration to cities (Crkvenčić 1981; Vresk 1972). Abandoned land (i.e. 
grasslands) was often termed "social fallow" (Hartke 1953) signifying the importance of social changes in land use and land cover changes.

After the break-up of Yugoslavia in 1991, the management of agricultural lands, including grassland areas, was not faced with problems of restitution, but still it went through the process of adapting to the new economic circumstances. Managed grasslands as a base for livestock had to deal with numerous unfavourable characteristics inherited from the socialist era - land holdings were mostly too small to sustain any form of commercial agriculture and had, on average, a very small number of cattle $(<2)$ per agricultural household which were kept in inadequate facilities. The lack of agricultural subsidies in the newly liberalized market had a further impact on changes in the traditional forms of agriculture, but to a lesser extent (Todorović and Drobnjaković 2010; Feldhofer and Deneš 1997).

This raises an important question about how the economic and demographic changes as well as bio-physical characteristics have influenced grasslands and grassland management in the post-socialist era. The data from the Croatian Environmental Agency (CEA) based on the Corine Land Cover gives us some information on changes in the land cover in Croatia during the studied period. According to CEA (Voća 2014), the areas consisting of grasslands have been slowly but constantly increasing in Croatia during the $1990-2012$ period and amount to around $21 \%$ of the surface area today. However, the grassland areas which remained unchanged in the studied periods have since reduced in size; so the overall increase comes from the changes in other types of land cover (usually forests and/or arable land) which are being converted to grasslands. Those changes are often temporary transitions from one land cover type to another, for example, agricultural land being permanently abandoned which eventually leads to shrub encroachment and forest succession, while permanent grasslands are endangered (Hellesen and Levin 2014; Plieninger 2006). Additionally, such data is only gathered on a national level and doesn't include local or regional characteristics. 
Furthermore, to the best of our knowledge, there are no analyses in Croatia or any other country of former Yugoslavia which deal with characteristics of the changes in grassland cover after the collapse of socialism. This paper aims to fill that gap by examining the changes in grassland cover and providing evidence of the factors contributing to those changes. By using an appropriate study site in Northern Croatia this research addressed the following specific objectives:

a) To map changes in grassland and agricultural land cover using repeated remotely-sensed images to assess the magnitude and distribution of such changes during the post-socialist period;

b) To investigate the relationships between changes in land use/cover and physical geographic and socio-economic factors at the local and regional scale;

c) To analyse the causal mechanism of land use/cover change by exploring the decisionmaking processes related to grassland management and livelihood strategies at the local/household scale.

\section{THE STUDY AREA}

The study was carried out in the Krapina-Zagorje County in Northern Croatia (Fig 1). Bordering Slovenia to the east, Zagreb to the south and Varaždin County to the north and east, it is a typical rural area of Croatia characterised with small dispersed settlements and traditional subsistence agriculture. With a population of 133,000 and a surface area of 1224 $\mathrm{km}^{2}$ it is the $4^{\text {th }}$ most densely populated region in the country. The average settlement size is less than 400 people and only $24 \%$ of the total population live in urban areas. 


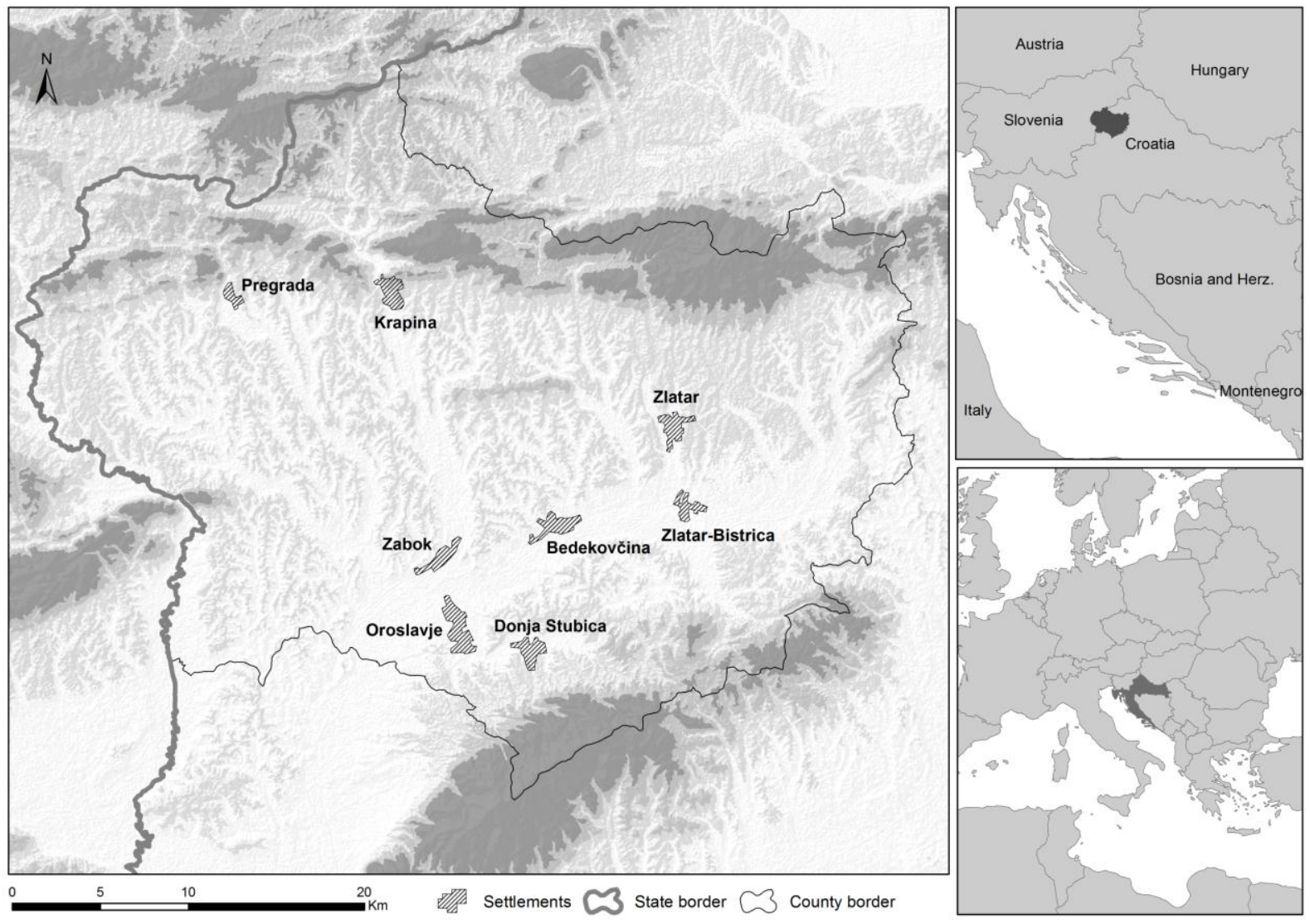

Fig 1. Study area of the Krapina-Zagorje County, Croatia

The area is characterized with a heterogeneous topography ranging from the alluvial plains of the Krapina river (around $150 \mathrm{~m}$ asl) to the peaks of Mt. Medvednica and Mt. Ivanščica reaching altitudes over $1000 \mathrm{~m}$. Most of the larger settlements are located in the lowlands, around major rivers and their hilly surroundings, and most of the mountain slopes are covered with dense forests (Cvitanović 2014). Krapina-Zagorje County is characterised by a humid continental climate with warm summers. The entire area receives between 850 and $1200 \mathrm{~mm}$ of precipitation per year, with peak precipitation occurring in the summer months (Filipčić 2001). Summers are warm with monthly average temperatures in July and August above $20^{\circ} \mathrm{C}$, and monthly averages in January are above $-3{ }^{\circ} \mathrm{C}$ (CMHS 2014).

Phytogeographically, the entire area of Croatia belongs to the climate zone of temperate forests and if it hadn't been for a long lasting human impact on the environment, 
the majority of the surface of the country would be covered with forests. All types of shrubs, pastures, meadows, clearances etc. are a result of anthropogenic influence on the primary forest cover (Alegro 2000). In the lower areas of the county, the typical central-European meadow community of Arrhenatheretum elatioris is commonly found, in particular in areas out of reach of flood waters. Surfaces covered by this community are very frequently transformed into arable land, having as a consequence the reduction in habitat diversity and thus also the reduction in biological diversity (Durbešić et al. 2006). In higher altitudes, the community of Brono-Plantaginetum mediae occurs most often (Jelaska et al. 2005). They are used mostly as meadows, mowed annually, or, rarely as pastures. These grassland communities are especially endangered due to disappearance of traditional pasturing (Durbešić et al. 2006; Topić et al. 2006). Thus, parts of the Krapina-Zagorje County are protected as Natura 2000 areas where the main reason stated for their protection is the existence of endangered grassland species and semi-natural dry grasslands. Their protection and conservation is seen as important for the entire continental biogeographical area of Europe (Topić et al. 2006).

According to the 2003 Agricultural Census, (Croatian Bureau of Statistics, 2015) around $22 \%$ of the Krapina-Zagorje County is covered with grasslands, the same level as the Croatian average. It is the highest percentage of grassland cover in the continental part of Croatia. Additionally, over $90 \%$ of the population practices traditional forms of agriculture and $98 \%$ of the agricultural land is privately owned, which is the highest percentage in all of Croatia (Croatian Bureau of Statistics 2011); therefore this region is seen as optimal for the study of agricultural land use change in traditional landscapes during post-socialism. 


\section{DATA AND METHODS}

This research is based on a mixed-method approach and combines remote sensing, quantitative data modelling, and a questionnaire survey. The detection of bio-physical changes in land use and land cover is based on the supervised classification of SPOT 2, Landsat TM and Landsat ETM+ satellite imagery for 1991, 2000 and 2011, respectively. Subsequently links between changes in land use and cover and potential environmental and socio-economic drivers of those changes are examined by multiple regression analysis. Such simple statistical models can help us in tracing the causal factors of the observed land change, but not the precise pathway of causal mechanism through which this causal factor is linked to the outcome (Meyfrodit 2000). Therefore, the nature of these established links is further examined through a detailed questionnaire survey conducted on a structured random sample of 285 households in the County. The survey represents an important aspect of the research also because omission of human decision making in an analysis of this type severely limits the potential application of its results (Rounsevell et al. 2012; Karali et al. 2014). Apart from analysing the links between the contributing factors and the land change to establish causality, the questionnaire survey also helped in gathering data which is not available from other sources and in assessing the results of the remote sensing and the regression modelling.

\subsection{Remote sensing analysis}

The changes in the surface of grassland areas in the county were analysed by remote sensing using SPOT 2 dataset from September $2^{\text {nd }} 1991$, and Landsat ETM+ datasets from September $10^{\text {th }} 2000$ and June $29^{\text {th }} 2011$. The satellite imagery was already georeferenced, terrain corrected, projected and preselected for low cloud cover. The images had relatively similar seasonal conditions to avoid phenological changes, and summer months were selected because the difference in vegetation of grassland areas and agricultural areas is the largest 
during that time. The vast majority of crops grown in the County are corn and wheat, which have much less chlorophyll in late summer. It made the classification of grasslands and arable fields into separate categories relatively easy.

The analysis was conducted using ESRI Arc Map 10.0 and eCognition 9.0 software. The multispectral images were segmented into three levels (scale parameters 40, 10 and 3) using mean values of all available bands except thermal band, with 0.1 weight for the shape criterion and 0.5 weight for the compactness criterion. Subsequently, an iterative process of supervised classification was conducted on all three levels with georeferenced ortho-photos used as auxiliary information during the sample selection. The resulting classes were categorized as "grasslands", "forest", "arable land" and "other".

The accuracy of the classification was measured through a confusion matrix where classified data was compared to the reference data representing the actual land use and land cover. For each map, 500 randomly generated points were created in ArcMap 10.0 software proportionally distributed within the land use/cover category, and compared to reference data. For 2011, Google Earth data was used as reference data and for 1991 and 2000 a combination of a topographic map of Croatia and a number of georeferenced photos whose availability for the selected region and year was limited. The overall classification accuracy achieved was around $90 \%$ for each studied year, with the kappa coefficient ranging from 0.75 (for 1991) to 0.79 (for 2011). Before the final comparison, the maps were visually analysed and with the help of orto-photos and several fieldworks, a part of the misclassified objects was manually corrected so the final accuracy is slightly higher.

The final maps were created by post-classification overlay. It contained information on both the spatial distribution of grassland at the beginning and the end of the studied periods, as well as quantitative spatially explicit data on land use/cover changes for these periods. The detected processes included the transition between grasslands and forests on one side, and the 
transition between grassland and arable land on other. The transition between grasslands and the category "other" (built-up, water, barren land etc.) comprises 3\% of the observed change and was not a part of the analysis.

\subsection{Regression analysis}

After the remote sensing analysis, a statistical analysis of contributing factors (variables) of land use/cover change was undertaken. A regression analysis was used in order to examine the relationship between the variables we hypothesised to influence spatial patterns of land cover change, but also to determine which of the hypothesised variables will be statistically significant predictors of the studied change.

Due to the fact that the socio-economic data gathered from Censuses and quantitative research cannot be assigned to pixels demonstrating changes in land use/cover, both remote sensing and socio-economic data were aggregated into larger spatial units (municipalities). In this way socio-economic data which influences the changes in grassland cover is aggregated into larger areas where its environmental impact is more visible and more manageable in subsequent modelling, although a certain data loss undoubtedly occurs (Wood and Skole 1998; Lambin et al. 2003; Overmars and Verburg 2005).

Explanatory variables of changes in grassland cover to be incorporated in the analysis were based on literature and expert knowledge of the area. Previous research has demonstrated the importance of bio-physical characteristics such as slope gradient, soil characteristics, or altitude as drivers of changes in grassland areas (Flinn et al. 2005; Benayas et al. 2007). However, changes in grassland areas are also heavily influenced by human activities, with variables such as population ageing, agricultural extensification or changes in employment often being utilized in statistical modelling (Kristensen et al. 2001; Kamwi et al. 2015; Monteiro et al. 2012). 
After the selection of all variables available from the 2011, 2001 and 1991 Censuses and other databases, a Pearson correlation was run between the variables to exclude one variable per pair if the relationship between them is higher than $r=0.8$. The variables were aggregated to a municipality level which was chosen as a unit of analysis because it represents the most detailed level on which most of our socio-economic and demographic variables were available. The municipalities are widely different in absolute scale, and therefore the variables used in regression modelling were standardized (Tab. 1). Regarding geo-physical variables, they were calculated via ArcGis 10.0 and based on digital elevation data from the Advanced Spaceborne Thermal Emission and Reflection Radiometer (ASTER GDEM). The altitude variable was divided into altitude categories representing the main landscape features of the region. The same landscape-based categorisation used for altitude was applied here. Above $400 \mathrm{~m}$ and on slopes $>24^{\circ}$ land cover is very homogeneous, rendering a more detailed categorisation of higher altitudes and slopes unnecessary.

Tab 1. Variables entered into the regression analysis

\begin{tabular}{|c|c|c|}
\hline Variable & Description & $\begin{array}{l}\text { Method of calculation } \\
\text { or standardization }\end{array}$ \\
\hline Population density & Ratio of population to surface area & \multirow{4}{*}{$\begin{array}{l}\text { Difference between } \\
\text { anniversary years for } \\
\text { each municipality }\end{array}$} \\
\hline Population ageing & $\begin{array}{l}\text { Ratio of people aged }>65 \text { to those } \\
\text { aged }<19\end{array}$ & \\
\hline Higher education structure & $\begin{array}{l}\text { Proportion of people with higher } \\
\text { education in population aged }>15\end{array}$ & \\
\hline Employment & $\begin{array}{l}\text { Proportion of employed people in } \\
\text { population aged }>15 \text { for }\end{array}$ & \\
\hline Up to $200 \mathrm{~m}$ altitude & $\begin{array}{l}\text { River valleys with major urbanized } \\
\text { settlements }\end{array}$ & \multirow{2}{*}{$\begin{array}{l}\% \text { of total territory for } \\
\text { each municipality }\end{array}$} \\
\hline $200-300 \mathrm{~m}$ altitude & $\begin{array}{l}\text { Hilly, densely populated traditional } \\
\text { rural areas }\end{array}$ & \\
\hline
\end{tabular}




\begin{tabular}{|l|l|}
\hline 300-400 m altitude & $\begin{array}{l}\text { Mountain slopes in contact zones } \\
\text { with human activities }\end{array}$ \\
\hline$>400 \mathrm{~m}$ altitude & Densely forested mountain zones \\
\hline Slopes $0^{\circ}-2^{\circ}$ & $\begin{array}{l}\text { River valleys with major urbanized } \\
\text { settlements }\end{array}$ \\
\hline Slopes $2^{\circ}-5^{\circ}$ & $\begin{array}{l}\text { Mostly hilly, densely populated } \\
\text { traditional rural areas }\end{array}$ \\
\hline Slopes $5^{\circ}-12^{\circ}$ & $\begin{array}{l}\text { Mostly mountain slopes in contact } \\
\text { zones with human activities }\end{array}$ \\
\hline Slopes $12^{\circ}-24^{\circ}$ & Densely forested mountain zones \\
\hline Slopes $>24^{\circ}$ &
\end{tabular}

Tab 2. Descriptive statistics of the variables entered into the regression analysis

\begin{tabular}{|l|c|c|c|c|c|}
\hline \multicolumn{1}{|c|}{ Variable } & N & Min & Max & Mean & $\begin{array}{c}\text { Std. } \\
\text { deviation }\end{array}$ \\
\hline Population density & 32 & 0.74 & 1.11 & 0.88 & 0.08 \\
\hline Population ageing & 32 & -76.60 & 1.80 & -31.80 & 18.20 \\
\hline Higher education structure & 32 & 2.10 & 9.20 & 4.60 & 1.66 \\
\hline Employment & 32 & -23.87 & 1.04 & -7.08 & 6.05 \\
\hline Altitudes up to $200 \mathrm{~m}$ & 32 & 0.00 & 90.82 & 39.43 & 27.25 \\
\hline Altitudes $200 \mathrm{~m}$ to $300 \mathrm{~m}$ & 32 & 9.17 & 76.44 & 38.99 & 13.89 \\
\hline Altitudes $300 \mathrm{~m}$ to $400 \mathrm{~m}$ & 32 & 0.00 & 52.23 & 12.79 & 15.51 \\
\hline Altitudes higher than $400 \mathrm{~m}$ & 32 & 0.00 & 46.41 & 8.76 & 12.33 \\
\hline Slopes $<2^{\circ}$ & 32 & 3.50 & 11.04 & 6.94 & 1.44 \\
\hline Slopes $2^{\circ}-5^{\circ}$ & 32 & 9.43 & 28.98 & 16.15 & 4.14 \\
\hline Slopes $5^{\circ}-12^{\circ}$ & 32 & 20.32 & 39.73 & 28.93 & 4.58 \\
\hline Slopes $12^{\circ}-24^{\circ}$ & 32 & 18.89 & 38.33 & 32.44 & 4.20 \\
\hline Slopes $>24^{\circ}$ & 32 & 2.25 & 30.30 & 15.51 & 6.15 \\
\hline
\end{tabular}

Before the analysis, the variables were plotted to a scatter diagram to check for linearity. Normality of the distribution was checked by Kolmogorov-Smirnov test. It indicated that none of the variables show a statistically significant departure from normal distribution. 
Subsequently the residuals were tested for homoskedasticity and all of the variables were entered into the regression model. Three models were created, for 1991-2000, 2000-2011 and 1991-2011.

The evaluation of the variables for each model was achieved through backward stepwise regression. Initially all 13 variables were included in the modelling, and using the stepwise procedure, variables whose exclusion does not statistically significantly decrease the explanatory power of the model were eliminated. In the end, six variables explaining the grassland-arable land transitions and nine variables explaining the grassland-forest transition remained in the model for 1991-2011. In the case of 2000-2011, only the variable of slope was statistically significant for grassland-arable land transition (slopes $0^{\circ}-2^{\circ}$ ), and in the 1991-2000 there were no statistically significant variables remaining in the model. Therefore the 1991-2011 model was used in this analysis.

\section{3. Questionnaire survey}

The final part of the research consisted of a questionnaire survey conducted on a systematic random sample of 285 households in four randomly selected municipalities in the County during 2013. One person per household, identified as a person making the decisions in relation to agriculture and household livelihood strategies, was surveyed. There were 46 questions where the respondents were asked about their socio-economic status, grassland management, pasturing practices, and other livelihood strategies. To account for the studied time period (1991-2011), the respondents were asked about any changes in their management practices or number of cattle in the last 20 years as well as plans for the future. The questionnaire was designed on the bases of the regression modelling results - data from the survey was not integrated into regression analysis but was used to complement the results from the modelling. 


\section{RESULTS}

\subsection{Remote sensing}

The object-based supervised classification of the multispectral imagery shows that the grasslands cover $21.5 \%$ of the County, which is generally in accordance with the existing data. In general, grasslands are the main land cover type at lower altitudes and flatlands largely alluvial plains of the major rivers in the county. In the areas lower than $200 \mathrm{~m}$ they are actually the dominant type of land cover (44.5\% of total surface area), and in altitudes higher than 400 m they take up less than $5 \%$ of the total land cover (Fig 2).

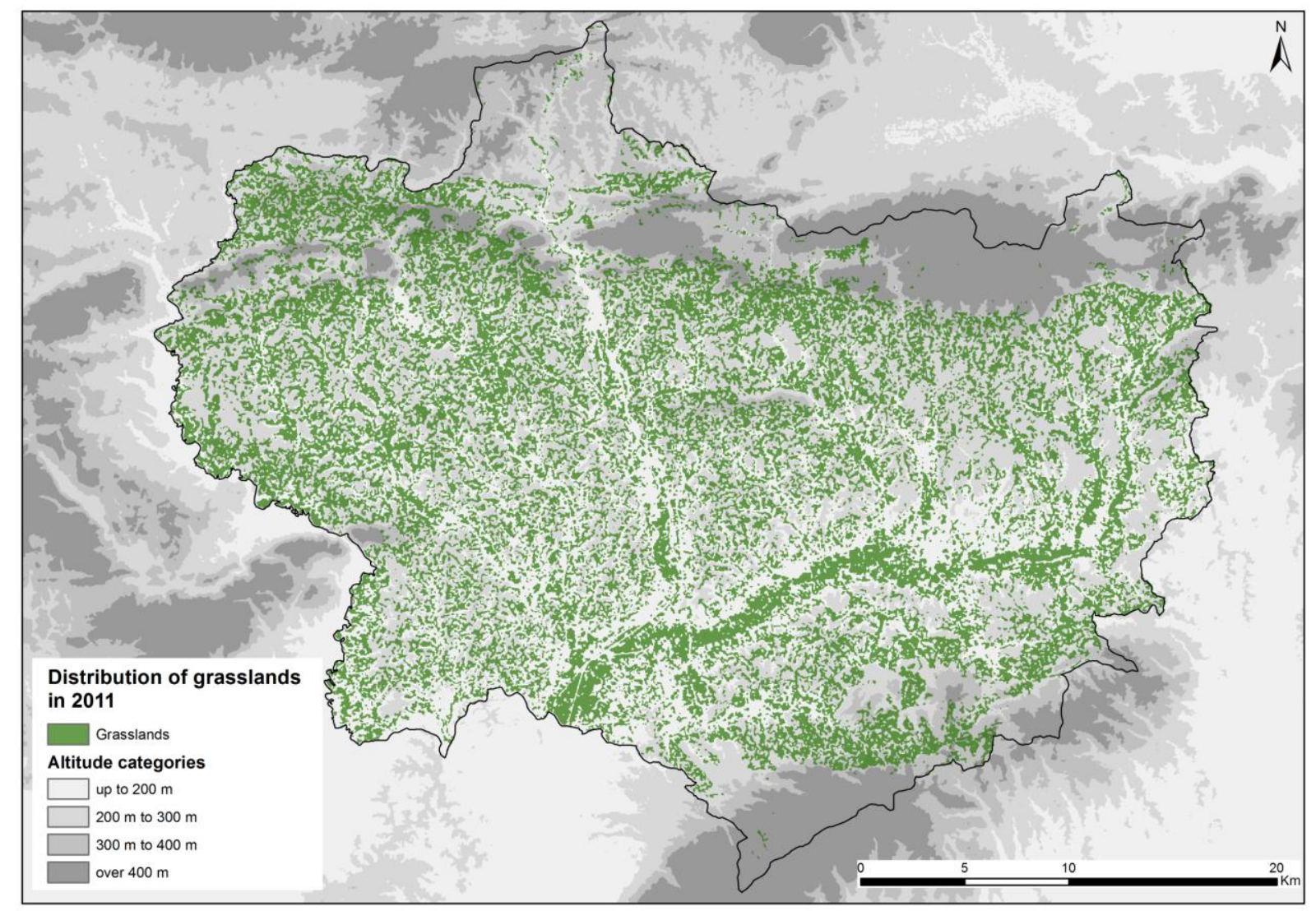

Fig 2. Distribution of grasslands in the Krapina-Zagorje County in 2011.

The results also show an overall 3\% loss in grassland areas in the 1991-2011 period which amounts to around $8.3 \mathrm{~km}^{2}$ (Fig 2). The rates of grassland loss have been lower in the 
first period $(0.8 \%)$, compared to the second period where they amounted to $2.2 \%$. This is in contrast to general trends in Croatia where grasslands areas have slightly increased in the studied period (Voća, 2014). However, only around $60 \%$ of grasslands in our study region did not undergo any transitions while the remaining $40 \%$ are linked to different types of land use and land cover transitions during that time. The biggest loss in grassland areas was recorded due to expansion of arable land in certain areas $\left(62 \mathrm{~km}^{2}\right)$ and the biggest gain due to abandoning arable land in other areas $\left(50 \mathrm{~km}^{2}\right)$. An overall grassland cover gain has been recorded at higher altitudes $(>300 \mathrm{~m})$ and on steeper slopes $\left(>12^{\circ}\right)$ while at all other altitudes and slopes an overall loss has been recorded (Fig 3).

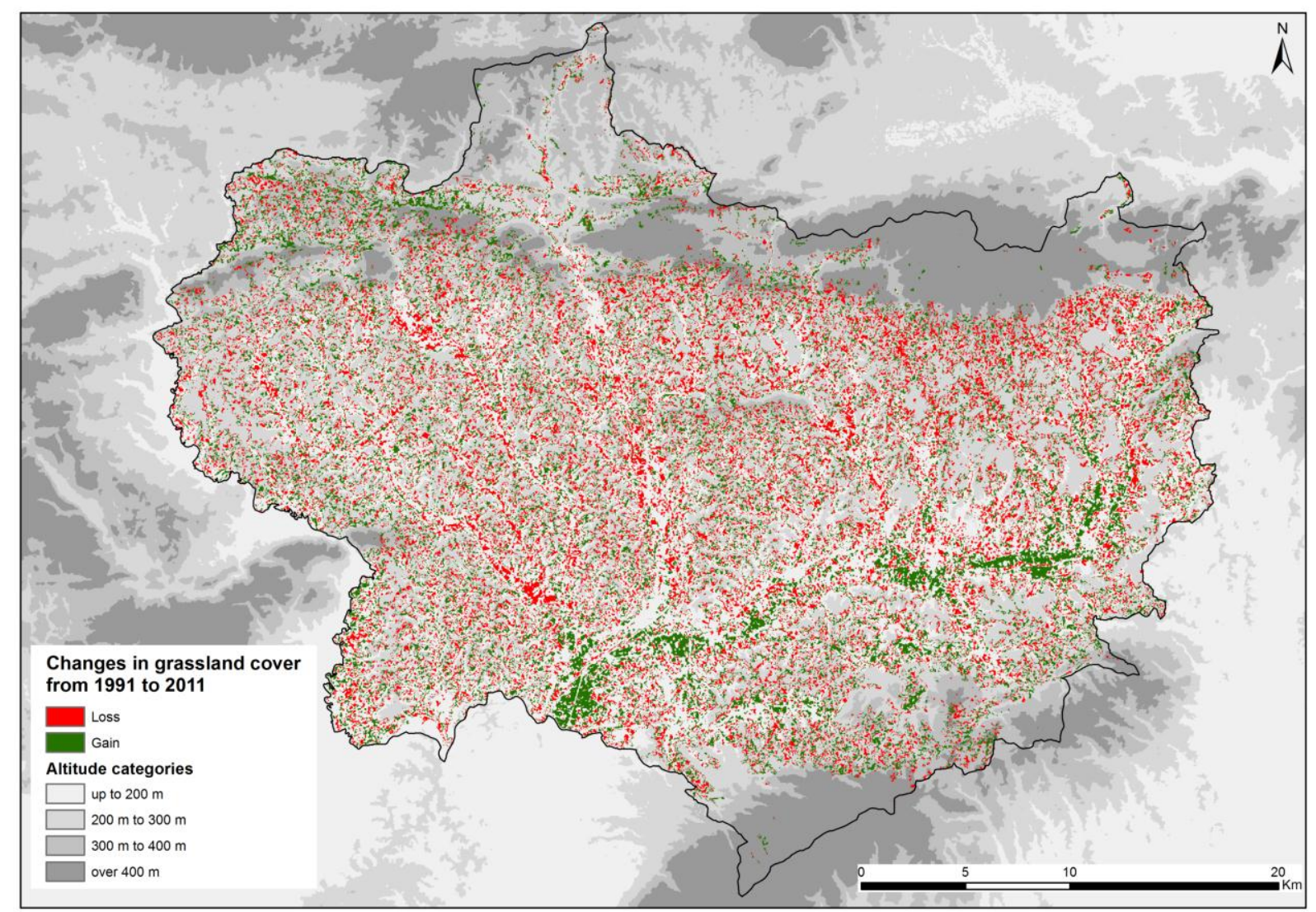

Fig 3. Changes in grassland cover in Krapina-Zagorje County in the 1991-2011 period 


\subsection{Regression Analysis}

The backward multiple regression analysis reduced the initial 13 variables that were entered in the first step to six variables explaining statistically significant amount of variability of the transition between grasslands and arable land (Tab. 3) and nine explaining the amount of variability of the transition between grasslands and forests in the 1991-2011 period (Tab. 4).

a) Regarding grasslands to arable land conversion, only physical-geographical variables remained in the model. The increase in rates of conversion to arable land is consistent with slopes $<2^{\circ}$ and the decrease in conversion to arable land is consistent with altitudes between $300 \mathrm{~m}$ and $400 \mathrm{~m}$; the model accounted for $29.3 \%$ of the variance (adjusted $\mathrm{R}^{2}$ ).

b) In case of the opposite process of abandonment of arable land, the variables remaining in the model were population density, higher education structure, altitudes higher than $400 \mathrm{~m}$, and slopes between $12^{\circ}$ and $24^{\circ}$; these variables accounted for $73.3 \%$ of the total variance. An increase in grassland to arable land transition showed a negative correlation with population density suggesting that areas characterized with more pronounced depopulation processes demonstrate higher rates of agricultural abandonment. The same process was observed in areas where the percentage of higher-educated people is on the rise. A negative correlation was established between abandonment of arable land and slopes between $12^{\circ}$ do $24^{\circ}$ and altitudes higher than $400 \mathrm{~m}$.

The results regarding physical-geographical variables are in accordance with the remote sensing results, confirming that grasslands are being converted to arable land in flatlands, while the processes in other parts of the region are more complex and their trajectories depend on the combination of several variables. 
Tab 3. Multiple regression coefficients for grassland - arable land changes

\begin{tabular}{|c|c|c|c|c|}
\hline $\begin{array}{l}\text { Independent variables for } \\
\text { grassland to arable land change }\end{array}$ & $\mathrm{B}$ & Beta & $\mathrm{R}$ & $\mathrm{R}^{2}$-adj. \\
\hline Altitudes 300 to $400 \mathrm{~m}$ & -0.066 & $0.036^{*}$ & \multirow[t]{2}{*}{0.338} & \multirow[t]{2}{*}{0.293} \\
\hline Slope $0^{\circ}$ do $2^{\circ}$ & 0.785 & $0.390^{*}$ & & \\
\hline \multicolumn{5}{|l|}{$\begin{array}{l}\text { Independent variables for } \\
\text { arable land to grassland change }\end{array}$} \\
\hline Population density & -17.986 & $-0.316^{*}$ & \multirow[t]{4}{*}{0.876} & \multirow[t]{4}{*}{0.733} \\
\hline Higher education structure & 0.892 & $0.327^{*}$ & & \\
\hline Altitudes higher than $400 \mathrm{~m}$ & -0.128 & $-0.347^{*}$ & & \\
\hline Slopes $12^{\circ}-24^{\circ}$ & -0.713 & $-0.659^{* * *}$ & & \\
\hline
\end{tabular}

* correlation is significant at the 0.05 level

** correlation is significant at the 0.01 level

c) In case of grassland to forest transition, the remaining variables were slopes $0^{\circ}-2^{\circ}(+)$, slopes $12^{\circ}-24^{\circ}(+)$, altitudes 300 do $400 \mathrm{~m}(-)$, employment (+) and population density (-) in which have accounted for $69.6 \%$ of the total variance.

d) In the case of the opposite process (of forest-to-grassland transition), the remaining variables were altitudes 200 to $300(+), 300$ to $400 \mathrm{~m}(+)$, slopes $5^{\circ}$ to $12^{\circ}(-)$, slopes higher than $24^{\circ}(-)$, population ageing (-), employment (+) and higher education structure (-), which have accounted for 66.2 of the total variance. 
Tab 4.Multiple regression coefficients for grassland - forest changes

\begin{tabular}{|c|c|c|c|c|}
\hline $\begin{array}{l}\text { Independent variables for } \\
\text { grassland to forest change }\end{array}$ & $\mathrm{B}$ & Beta & $\mathrm{R}$ & $\mathrm{R}^{2}$-adj. \\
\hline Population density & -9.735 & $-0.500^{* *}$ & \multirow[t]{5}{*}{0.863} & \multirow[t]{5}{*}{0.696} \\
\hline Employment & 0.072 & $0.337^{*}$ & & \\
\hline Slope $0^{\circ}$ do $2^{\circ}$ & 0.444 & $0.497^{*}$ & & \\
\hline Slope $12^{\circ}$ to $24^{\circ}$ & 0.202 & $0,073^{*}$ & & \\
\hline Altitudes from 300 to $400 \mathrm{~m}$ & -0.047 & $-0.571^{* *}$ & & \\
\hline \multicolumn{5}{|l|}{$\begin{array}{l}\text { Independent variables for } \\
\text { forest to grassland change }\end{array}$} \\
\hline Population ageing & -0.064 & $-0.505^{*}$ & \multirow[t]{7}{*}{0.859} & \multirow[t]{7}{*}{0.662} \\
\hline Higher education structure & -0.603 & $-0.432^{*}$ & & \\
\hline Employment & 0.098 & $0.255^{*}$ & & \\
\hline Altitudes 200 to $300 \mathrm{~m}$ & 0.071 & $0.425^{*}$ & & \\
\hline Altitudes 300 to 400 & 0.126 & $0.843^{* *}$ & & \\
\hline Slopes $5^{\circ}-12^{\circ}$ & -0.390 & $-0.770^{*}$ & & \\
\hline Slopes $24^{\circ}$ and higher & -0.414 & $-1.096^{*}$ & & \\
\hline
\end{tabular}

These results confirm that the process of forest clearing in altitudes between 300-400 $\mathrm{m}$ and slopes $12^{\circ}$ to $24^{\circ}$ (and to lesser extent in the altitudes between 200 to $300 \mathrm{~m}$ ) is connected to the conversion of forests to grasslands in those areas, be they temporary or otherwise. They are mostly forested mountain slopes in contact zones with human activities. On the other hand, slopes $5^{\circ}-12^{\circ}$ and slopes $>24^{\circ}$ are negatively connected to conversion of forest to grasslands.

Regarding socio-economic and demographic factors, the process of forest clearance and its conversion to grasslands is consistent with areas where population ageing is not as rapid and areas with comparatively smaller increases in the amount of people with higher education. The opposite process of forest succession on grassland is consistent with areas with 
decreasing population density. Change in employment rates was significant predictor for both forest to grassland and grassland to forest change, probably due to different pattern of correlations with other variables in the model.

\subsection{Questionnaire survey}

The analysis of the questionnaire survey gave us additional insight into the causes of the observed changes in grassland areas and in part helped in assessing the results acquired in other parts of this research. The average age of the respondents was 43 years and $41 \%$ were male. The average household size of was 3.9 members; the household statistics in this survey generally corresponded to the 2011 census data.

According to the results, $89 \%$ of the surveyed households own arable land and practice some form of agriculture. The median size for a land holding of arable land is 3 hectares distributed into three plots. Every second surveyed household has grasslands with a median size of 2.9 hectares distributed on 2.5 land plots; only $10 \%$ of the surveyed households have land holdings larger than 15 hectares. Grasslands are or were reportedly used as pastures for cattle or as fodder during wintertime, and also as land which hasn't been "put to use" - as much as $22 \%$ of arable land is reported as temporarily uncultivated and left to overgrow. The reasons most often mentioned for lack of cultivation of agricultural land is advanced age or illness (31\%), economic reasons (25\%), and lack of time (19\%).

In regards to pasturing, it was found that as many as $93 \%$ of the surveyed households don't own livestock. In the studied period $1991-2011,61 \%$ of households significantly reduced the number of livestock (mostly cattle) or completely stopped pasturing with only $25 \%$ of the respondents having never practiced pasturing in the first place. The main reasons stated for abandoning such practices were lack of profit (35\%), advancing age or illness 
(26\%), and lack of time (21\%). A statistically significant difference between the reasons for abandoning pasturing and the age of respondents was established $\left(\chi^{2}=61,706, \mathrm{df}=16, \mathrm{p}<0.01\right)$. The highest number of respondents who have never practiced pasturing is found in the youngest category of respondents (up to 39 years of age, 34\%), and the highest number of people who have practiced it in the studied period is found in the oldest category of respondents (> 59 years of age, $17 \%$ ).

Despite the trends moving away from pasturing and livestock production, as much as $87 \%$ of the respondents reportedly try to maintain most or all of the grasslands in their possession, mostly by mowing. The reasons most often stated for abandoning grassland management are distance (33\%), lack of profit (33\%) and advancing age or illness (13\%).

\section{DISCUSSION}

Agricultural areas in the Krapina-Zagorje County have recorded strong rates of conversion of arable land to grasslands and vice versa in the post-socialist period. Areas seeing general depopulation trends and population ageing, but also increases in the amount of educated people are characterized by shrub encroachment and farmland abandonment. On the other hand, flatlands and lowland areas in the County are seeing higher rates of grassland to arable land conversion, demonstrating that both socio-economic and bio-physical variables are influencing land cover change in the region.

The results gathered from the remote sensing and the regression analysis show that the bio-physical variables of slope and altitude had the greatest influence on the dependent variable of grassland change. In all four of our models it was the most important variable. It was further confirmed by our questionnaire survey where the question of accessibility was often reported as one of the main determining factors for land abandonment. Similar studies conducted in Romania, Czech Republic and Slovakia have found that intensive land use is 
associated with a lower slope grade and elevation, while the highest abandonment rates are to be found on steeper slopes and at higher elevations (Kuemmerle et al. 2009; Druga and Faltan 2014; Lieskovský et al. 2015).The profitability of farming decreased the most in these areas due to issues of mechanization and accessibility. Access to infrastructural facilities and proximity to local markets strongly affects the profitability of crop cultivation due to higher transportation costs for inputs and outputs (Kuemmerle et al. 2009; Pazur et al. 2014). The socialist legacies of expansive land production are influenced by new market forces in favourable areas, while economically and environmentally marginal agricultural areas are left uncultivated (Griffiths et al. 2013; Prishchepov et al. 2013).

At the same time, areas with unfavourable environmental characteristics in our study (higher altitudes and steeper slopes) are characterised with unfavourable socio-economic trends as well, such as population ageing, depopulation, and lower education levels. All of these factors are found to strongly benefit agricultural abandonment. Similar socioeconomic factors were emphasized as determinants of agricultural land abandonment in other countries as well, e.g. studies conducted in Albania (Müller and Sikor 2006) and Slovakia (Pazur et al. 2014).

The area of agriculture witnessing the biggest changes in Croatia is pasturing. In general, all business and services connected to pasturing and livestock production have recorded a sharp decline in the last two decades. An annual loss in number of livestock in Croatia has been reported at 5-10\% in 2012-2014 (Croatian Bureau of Statistics 2011; Grgić and Zrakić 2015). According to the official data of the Krapina-Zagorje County, in the 19992009 period the number of cattle in the county decreased by $41 \%$ (Croatian Ministry of Agriculture 2013). Similar results have been recorded by this research - as many as $61 \%$ of surveyed households have significantly reduced the number of livestock or completely stopped pasturing during the studied period. The main reasons stated for abandoning such 
practices were lack of profit, advancing age or illness, and lack of time. The category of age was proven to be a statistically significant variable in the abandonment of pasturing practices in our questionnaire.

The results also show that despite the strong changes in agricultural (pasturing) practices in the studied region, as many as $87 \%$ of the respondents still try to maintain most or all of the grasslands in their possession, either by mowing, burning or grazing. This can partially be explained by traditional values typical for rural population. The research dealing with the values and beliefs of respondents towards agriculture and living in rural areas in the same region (Cvitanović et al. 2016) shows that the older population is less educated, and tends to hold on to traditional values of agriculture and the necessity of preserving land management traditions. The idea of abandoning the land is seen as a disgrace, and the land should be cultivated at any cost. However, the highest portion of respondents who have drastically decreased their agricultural activities belong to the oldest age category. As many as $1 / 3$ of the older respondents say that they completely abandoned farming during the studied period, and old age and illness were the main reasons in over $50 \%$ of cases. In regards to pasturing, again it is the oldest category of respondents that has mostly abandoned it as a livelihood strategy.

Agricultural subsidies are not seen as having an important role in encouraging the aforementioned agricultural practices in our research. Based on data gathered from the questionnaire, only $21 \%$ of the respondents not receiving any agricultural subsidies would take on agriculture or expand their current practices in agriculture with subsidies, while $65 \%$ of respondents who receive subsidies wouldn't abandon their agricultural practices without subsidies. In comparison, the withdrawal of subsidies has played an important role in postsocialist grassland conversion in the area of the Carpathians and Albania, where agricultural production was possible even in marginal areas thanks to state subsidies during socialism, but 
the issue of accessibility has become increasingly important under free market conditions (Kuemmerle et al. 2008; Müller et al. 2013). On the other hand, agricultural subsidies in Croatia during socialism were predominantly aimed at socialized enterprises, and traditional farms were mostly excluded from such practices. More or less the same policies were continued under open market circumstances, where large producers could more easily benefit from agricultural subsidies. These findings were confirmed by our questionnaire, where only around $10 \%$ of respondents in traditional agricultural households received subsidies. Furthermore, the analysis by Franić et al. (2011) shows that mostly due to frequent changes in legislature and criteria for receiving subsidies from 1998 to 2008, the subsidies actually had little effect in increasing any kind of agricultural production in Croatia, despite their financial increase of $4 \%$ per year during the studied period.

The results from the regression modelling also point to the importance of employment changes as a statistically significant predictor of changes in grassland cover. During market reforms in 1990' a number of obsolete industries in the former Yugoslavia collapsed, often in less developed regions and in traditional agricultural areas with labour intensive industry (Vodopivec, 1994). The collapse of predominantly textile industry in the Krapina-Zagorje County during the same period created high levels of unemployment and a decrease in household income which, in turn, resulted in potentially new livelihood strategies. Almost a third of the respondents from the questionnaire reportedly practice agriculture as an important, if not only source of food for the household. Further $10 \%$ describe agriculture as an important source of additional income generated by selling produce to friends and neighbours. On the other hand, younger, more educated people tend commute outside the region in search of employment. Such migration to more distant, large urban centres contributed to a decrease of the "peasant-workers" practices which had maintained the smallholder agriculture for almost 50 years. It is further confirmed by the research conducted by Cvitanović et al. (2016) 
showing that longer commute and longer working hours are preventing people from practicing more agriculture. Therefore, changes in employment could have caused both decrease and increase in agricultural practices with concomitant correlations to other contributing factors.

All of these social and economic changes have left their mark on the landscape. The processes of ageing and depopulation as well as socio-economic restructuring have resulted in decreases or total abandonment of traditional agricultural activities, rather than shifting to another (agricultural) activity which is less labour intensive (Pantić and Miljković 2010). The circumstances of increased education levels and the migration of the younger, educated workforce from rural areas to urban centres outside the county resulted in rural areas being abandoned and left to overgrow (Spevec 2009). Abandoned fields left to overgrowth first become grasslands, and then through secondary succession they become forests. Highereducated respondents are younger on a statistically significant level, with higher income and lower agricultural employment. The largest number of respondents who haven't practiced any form of agriculture in the studied period belongs to the youngest category.

Decreasing interest in traditional farming practices have been noted in other parts of the world as well (Lieskovský et al. 2015; MacDonald et al. 2000; Snyder 1996). The lost interest in farming mainly in the younger generation, the lack of successors in agriculture, health related issues and age for older farmers are found to be factors that have driven the abandonment of agriculture in Slovakia (Lieskovský et al. 2015). Such results show that the partial de-agrarization characteristic for the socialist period has become a full de-agrarization in the post-socialist period, with the main impetus being education, rather than employment, as was the case during socialism (Vresk 1972). Registered changes are in part consequences of households' adjustment to the new realities of ageing members, lower prices of agricultural produce, and increase in education levels. Such adaptations include geographic 
factors as well, such as distance from populated centres and accessibility of the land, altitude and soil quality.

In contrast to declines recorded in some places, certain areas have recorded an increase in agricultural activities. Besides growing organic food, commercial agricultural systems such as flower and pine-tree production were mentioned in the questionnaire, as well as agricultural practices connected to rural tourism. Such new trends have resulted in the expansion of arable at the expense of grasslands, and can be attributed to new values and lifestyle trends which have emerged in the last decade or so. Around $26 \%$ of the respondents say that the reason for practicing agriculture is acquiring healthy, fresh, organic food, and a number of times agriculture was described as a hobby or a favourite pastime. Considering the fact that the increase in farmland areas has occurred in flatlands and lower areas, it can also be seen as an adjustment of household strategy regarding accessibility. Arable land on higher elevations and steeper slopes far from urban centres, from one's place of living or major roads is being increasingly abandoned, while grassland areas closer to households are being increasingly converted to new arable land, partly for commercial use or for use by life-style farmers. Such shifts from an agricultural orientation production to a preference for natural and cultural amenities have been well documented in a number of post-industrial countries in Western Europe, Australia and the USA. Agricultural land in this case is used for recreation, enjoyment of its aesthetic qualities, and to experience the rural life-style (Sorice et al. 2014; Johnson 2008).

All of the previously described processes have resulted in changes in grassland areas which are seen as one of the key areas for preserving biodiversity in Europe. Although Croatia in general is characterised by an overall net gain in the grassland areas $(0.5 \%$ in the 1990 - 2012 period) and the overall net loss of grassland areas in the studied region in the $1991-2011$ period is very small (3\%), the percentage of permanent grasslands is decreasing 
both nationally and regionally with only $60 \%$ of grassland areas in the Krapina-Zagorje County remaining unchanged during the studied period.

\section{CONCLUSION}

The traditional agricultural system based on small landholding and pasturing, typical for rural areas throughout Yugoslavia, has survived 50 years of socialist experiments which favoured industrial development over agriculture. After the demise of socialism, changes such as the liberalization of the market, collapse of obsolete industries and a lack of agricultural subsidies have had a major impact on traditional agricultural practices. The so-called "peasant-workers" have aged and are slowly abandoning agriculture, while new generations, brought up in different social and economic circumstances are increasingly without any agricultural experience. Traditional forms of pasturing are suffering from greatest changes with the number of cattle per household being halved in the period of one decade. It is in part a consequence of the de-ruralization and de-agrarization processes that began in the socialist period.

After 20 years of post-socialist management, such changes are becoming visible in the landscape, with probably the greatest impact on managed grassland areas. Grasslands are no longer used as pasture or winter fodder for cattle (which are no longer being kept), nor in new, modern, types of agriculture based on higher yields or life-style choices, but are still managed in part due to cultural and traditional reasons, predominantly by older population. New market forces seem to have exacerbated the differences between socially and geographically favourable areas and those in decline, resulting in general decrease in permanent grasslands. With the continual of the aforementioned trends of population ageing, increase in education levels in younger population and migration from rural areas to cities, in order to preserve 
these valuable hotspots of biodiversity, it is becoming increasingly necessary to introduce a system which would find a new function for grasslands.

\section{ACKNOWLEDGEMENTS}

This paper has been realised within the projects "Environmental change and cultural Landscape as a Development Resource" (supported by the Ministry of Science, Education and Sport of the Republic of Croatia) and "Croruris - A scenario-based approach to discuss planning and development of Croatian rural areas" (Project HRZZ-4513 supported by the Croatian Science Foundation). Any opinions, findings, and conclusions or recommendations expressed in this material are those of the authors and do not necessarily reflect the views of Croatian Science Foundation. SPOT 2 images used in this paper were acquired from the CNES program (Incentive for the Scientific use of Images from the SPOT System) of the French National Centre of Space Research (Centre National d'Etudes Spatiales). The authors would like to thank Christopher Grey Kaufmann for his English translation and language editing.

\section{REFERENCES}

Allcock, J. B. (2000). Explaining Yugoslavia. C. Hurst \& Co. Publishers.

Alegro, A. (2000). Vegetacija Hrvatske. Zagreb, Croatia: Botanički zavod PMF-a, Sveučilište u Zagrebu.

Baránková, Z., Dobrovodská, M., Štefunková, D., Babicová, D., Moyzeová, M., \& Petrovič, F. (2011). Participation of local people on identifying the landscape values and future development in historical agricultural landscapes. Ekologia, 30(1), 216-228.

http://doi.org/10.4149/ekol_2011_02_216

Baumann, M., Kuemmerle, T., Elbakidze, M., Ozdogan, M., Radeloff, V.C., Keuler, N.S., Prishchepov, V., Kruhlov, I. \& Hostert, P. (2011). Patterns and drivers of post-socialist farmland abandonment in Western Ukraine. Land Use Policy, 28(3), 552-562. http://doi.org/ 10.1016/j.landusepol.2010.11.003

Benayas, J. M. R., Martins, A., Nicolau, J. M. \& Schulz, J. (2007). Abandonment of agricultural land: an overview of drivers and consequences. CAB Reviews Perspectives in 
Agriculture Veterinary Science Nutrition and Natural Resources, 2(057).

http://doi.org/10.1079/PAVSNNR20072057

Bićanić, R. (2010). Economic Policy in Socialist Yugoslavia. Cambridge University Press.

Biró, M., Czúcz, B., Horváth, F., Révész, A., Csatári, B. \& Molnár, Z. (2013).Drivers of grassland loss in Hungary during the post-socialist transformation (1987-1999). Landscape Ecology, 28(5), 789-803.http://doi.org/ 10.1007/s10980-012-9818-0.

Caraveli, H. (2000). A comparative analysis on intensification and extensificationin mediterranean agriculture: dilemmas for LFAs policy. Journal of Rural Studies, 16, 231-242.

CMHS Croatian Meteorological and Hydrological Service. (2014). Retrieved from http://klima.hr/ocjene_arhiva_e.html on 27th of April 2015

Crkvenčić, I. (1981). Socijalnogeografski aspekti pojave ugara, odnosno neobrađenih oranica. Geografski glasnik, 43(1), 95-106.

Croatian Bureau of Statistics. (2011). Census 2011. Retrieved from www.dzs.hr on 12th of January 2016.

Croatian Bureau of Statistics. (2015). Agricultural Census 2003. Retrieved from www.dzs.hr/Hrv/censuses/Agriculture2003/census_agr.htm on 3rd of December 2015.

Croatian Ministry of Agriculture (2013). Strategija ruralnog razvoja RH 2008.-2013. Retrieved from http://www.mps.hr/default.aspx?id=3652 on 11th of October 2014.

Cvitanović, M., Blackburn, G. A., \& Jepsen, M. R. (2016). Characteristics and drivers of forest cover change in the post-socialist era in Croatia: evidence from a mixed-methods approach. Regional Environmental Change, 1-13. http://doi.org/10.1007/s10113-016-0928-0

Cvitanović, M. (2014). Land-use and Land-cover Changes in the Krapina-Zagorje County from 1991 to 2011. Hrvatski geografski glasnik, 76(1), 41-59.

Diogo, V. \& Koomen, E. (2012). Land-Use Change in Portugal, 1990-2006: Main Processes and Underlying Factors. Cartographica: The International Journal for Geographic Information and Geovisualization, 47(4), 237-249. http://doi.org/10.3138/carto.47.4.1504

Druga, M. \& Faltan, V. (2014). Influences of Environmental Drivers on Land Cover Structure and its Long-Term Changes: a Case Study of the Villages of Malachov and Podkonice in Slovakia. Moravian Geographical Reports, 22(3), 29-41.

http://doi.org/10.2478/mgr-2014-0016,

Durbešić, P., Vujčić-Karlo, S. \&Jelaska, L. S̆. (2006). Abundance and seasonal dynamics of arthropod in the meadow community Arrenatheretum elatioris near Varaždin, Croatia. Periodicum Biologorum, 108(1), 3-10.

Feldhofer, S. \& Deneš, S. (1997). Povećanje mliječnosti krava - temeljni zadatak mljekarstva Hrvatske. Mljekarstvo, 47 (1), 45-55.

Filipčić, A. (2001). Razgraničenje Koeppenovih klimatskih tipova Cf i Cs u Hrvatskoj. Acta Geographica Croatica, 35, 7-17. 
Flinn, K. M., Vellend, M., \& Marks, P. 1. (2005). Environmental causes and consequences of forest clearance and agricultural abandonment in central New York, USA. Journal of Biogeography, 32(3), 439-452. http://doi.org/10.1111/j.1365-2699.2004.01198.x

Franić, R., Marinović, M. \& Zrakić, M. (2011). Utjecaj državnih potpora na vrijednost i samodostatnost poljoprivredne proizvodnje u Hrvatskoj. Agronomski glasnik, 73(4-5), 227244.

Fürst Bjeliš, B., Cvitanović, M. \& Durbešić, A. (2015). Fire risk incidence over the last 200 years; Case study in the Mediterranean Croatia. X International Seminar: Overarching Issues of the European Area, At Univesidade do Porto; Faculdade de Letras, Porto. DOI: 10.13140/RG.2.1.2373.1362

Gerard, F., Petit, S., Smith, G., Thomson, A., Brown, N., Manchester, S. ...Feranec, J. (2010). Land cover change in Europe between 1950 and 2000 determined employing aerial photography. Progress in Physical Geography, 34(2), 183-205. http://doi.org/10.1177/0309133309360141

Grgić, I., \& Zrakić, M. (2015). Samodostatnost Republike Hrvatske u proizvodnji goveđeg mesa. Meso, 8(1), 51-56.

Griffiths, P., Müller, D. Kuemmerle, T.\& Hostert, P. (2013). Agricultural land change in the Carpathian ecoregion after the breakdown of socialism and expansion of the European Union. Environmental Research Letters, 8(4), 1-13. http://doi:10.1088/1748-9326/8/4/045024

Hartke, W. (1953). Die Soziale Differenzierung der Agrar-Landschaft im Rhein-Main Gebiet. Erdkunde, 7, 11-27.

Hellesen, T., \& Levin, G. (2014). Methodology to estimate loss of semi-natural grasslands due to shrub encroachment in Denmark from 1965 to 2010-a sample-based study using dot grids on aerial photographs. Journal of Land Use Science, 9(3), 331-348.

http://doi.org/10.1080/1747423X.2013.786152

Hietel, E., Waldhardt, R., \& Otte, A. (2007). Statistical modelling of land-cover changes based on key socio-economic indicators. Ecological Economics, 62(3-4), 496-507. http://doi.org/10.1016/j.ecolecon.2006.07.011

Horvat, Z. (2014). Upotreba satelitskih snimaka Landsat za utvrđivanje promjena u načinu upotrebe i pokrovu zemljišta u Međimurskoj županiji u Hrvatskoj. Hrvatski Geografski Glasnik, 75(2), 5-28.

IUCN (1991). The Lowland Grasslands of Central and Eastern Europe. International Union for Conservation of Nature and Natural Resources. Oxford: Information Press.

Jelaska, S. D., Kušan, V., Peternel, H., Grgurić, Z., Mihulja, A., \& Major, Z. (2005). Vegetation mapping of Žumberak - Samoborsko gorje Nature Park, Croatia, using Landsat 7 and field data. Acta Botanica Croatica, 64(2), 303-311.

Johnson, B. E. (2008). Nature, Affordability, and Privacy as Motivations for Exurban Living. Urban Geography, 29(7), 705-723. http://doi.org/10.2747/0272-3638.29.7.705

Karali, E., Brunner, B., Doherty, R., Hersperger, A., \& Rounsevell, M. (2014). Identifying the Factors That Influence Farmer Participation in Environmental Management Practices in Switzerland. Human Ecology,42(6), 951-963. http://doi.org/10.1007/s10745-014-9701-5 
Kamwi, J. M., Chirwa, P. W. C., Manda, S. O. M., Graz, P. F., \& Kätsch, C. (2015). Livelihoods, land use and land cover change in the Zambezi Region, Namibia. Population and Environment, 37(2), 207-230. http://doi.org/10.1007/s11111-015-0239-2

Komac, B., Kefi, S., Nuche, P., Escós, J., \& Alados, C. L. (2013). Modeling shrub encroachment in subalpine grasslands under different environmental and management scenarios. Journal of Environmental Management, 121, 160-169.

http://doi.org/10.1016/j.jenvman.2013.01.038

Kristensen, S. P., Thenail, C., \& Kristensen, L. (2001). Farmers' involvement in landscape activities: an analysis of the relationship between farm location, farm characteristics and landscape changes in two study areas in Jutland, Denmark. Journal of Environmental Management, 61(4), 301-318. http://doi.org/10.1006/jema.2000.0409

Kuemmerle, T., Perzanowski, K., Chaskovskyy, O., Ostapowicz, K., Halada, L., Bashta, A.T., Kruhlov, I., Hostert, P., Waller, D.M. \& Radeloff, V.C, (2010). European bison habitat in the Carpathian Mountains. Biological Conservation, 143(4), 908-916.

http://dx.doi.org/10.1016/j.biocon.2009.12.038.

Kuemmerle, T., Müller, D., Griffiths, P., \& Rusu, M. (2009). Land use change in Southern Romania after the collapse of socialism. Regional Environmental Change, 9(1), 1-12. http://doi.org/10.1007/s10113-008-0050-z

Kuemmerle, T., Hostert, P., Radeloff, V., Linden, S., Perzanowski, K. \& Kruhlov I. (2008). Cross-border comparison of post-socialist farmland abandonment in the Carpathians.

Ecosystems, 11, 614-628. http://doi.org:10.1007/s10021-008-9146-z.

Lambin, E. F., Geist, H. J., \& Lepers, E. (2003). Dynamics of Land-Use and Land-Cover Change in Tropical Regions. Annual Review of Environment and Resources, 28(1), 205-241. http://doi.org/10.1146/annurev.energy.28.050302.105459

Lerman, Z. (2001). Agriculture in transition economies: from common heritage to divergence. Agricultural Economics, 26(2), 95-114. http://doi.org/10.1016/S0169-5150(00)00107-9

Lieskovský, J., Bezák, P., Špulerová, J., Lieskovský, T., Koleda, P., Dobrovodská, M., Bürgi, M. \& Gimmi, U. (2015). The abandonment of traditional agricultural landscape in Slovakia Analysis of extent and driving forces. Journal of Rural Studies, 37, 75-84. http://dx.doi.org/10.1016/j.jrurstud.2014.12.007

Lukić, A. (2012). Mozaik izvan grada: tipologija ruralnih i urbaniziranih naselja Hrvatske. Samobor: Meridijani.

MacDonald, D., Crabtree, J. R., Wiesinger, G., Dax, T., Stamou, N., Fleury, P., Gutierrez Lazpita, J. \& Gibon, A. (2000). Agricultural abandonment in mountain areas of Europe: Environmental consequences and policy response. Journal of Environmental Management, 59(1), 47-69.

Maestre, F. T., Bowker, M. A., Puche, M. D., Belén Hinojosa, M., Martínez, I., GarcíaPalacios, P., ...Escudero, A. (2009). Shrub encroachment can reverse desertification in semiarid Mediterranean grasslands. Ecology Letters, 12(9), 930-941.

http://doi.org/10.1111/j.1461-0248.2009.01352.x 
Martínez, J., Vega-Garcia, C., \& Chuvieco, E. (2009). Human-caused wildfire risk rating for prevention planning in Spain. Journal of Environmental Management, 90(2), 1241-1252. doi:10.1016/j.jenvman.2008.07.005

Meshinev, T., Apostolova, I., Kachaunova, E., Velchev, V., Bondev, I. (2000). Flora and plant communities. In A. Popov, T. Meshinev (Ed.), High mountain treeless zone of the Central Balkan National Park. Biological diversity and problems of its conservation (pp.3-5). Sofia: BSBCP.

Meyfroidt, P. (2016). Approaches and terminology for causal analysis in land systems science. Journal of Land Use Science, 11(5), 501-522.

http://doi.org/10.1080/1747423X.2015.1117530

Monteiro, A. T., Fava, F., Hiltbrunner, E., Della Marianna, G., \& Bocchi, S. (2011).

Assessment of land cover changes and spatial drivers behind loss of permanent meadows in the lowlands of Italian Alps. Landscape and Urban Planning, 100(3), 287-294. http://doi.org/10.1016/j.landurbplan.2010.12.015

Munteanu, C., Kuemmerle, T., Boltiziar, M., Butsic, V., Gimmi, U., Halada, L. \& Radeloff, V. C. (2014). Forest and agricultural land change in the Carpathian region-A meta-analysis of long-term patterns and drivers of change. Land Use Policy, 38, 685-697.

http://doi.org/10.1016/j.landusepol.2014.01.012

Müller, D., Leitão, P. J., \& Sikor, T. (2013). Comparing the determinants of cropland abandonment in Albania and Romania using boosted regression trees. Agricultural Systems, 117, 66-77. http://doi.org/10.1016/j.agsy.2012.12.010

Müller, D., \& Sikor, T. (2006). Effects of postsocialist reforms on land cover and land use in South-Eastern Albania. Applied Geography, 26(3-4), 175-191.

http://doi.org/10.1016/j.apgeog.2006.09.002

Nunes, M. C. S., Vasconcelos, M. J., Pereira, J. M. C., Dasgupta, N., Alldredge, R. J., \& Rego, F. C. (2005). Land Cover Type and Fire in Portugal: Do Fires Burn Land Cover Selectively? Landscape Ecology, 20(6), 661-673. doi:10.1007/s10980-005-0070-8

Opršal, Z., Kadivo, P. \& Machar, I. (2016). The role of selected biophysical factors in longterm land-use change. Applied Ecology and Environmental Research, 14(2), 23-40.

Orazem, F. (1989). Agriculture under socialism. Slovene Studies, 1111(2), 215-222.

Osawa, T., Kohyama, K., \& Mitsuhashi, H. (2013). Areas of Increasing Agricultural Abandonment Overlap the Distribution of Previously Common, Currently Threatened Plant Species. PLoS ONE, 8(11).http://doi.org/10.1371/journal.pone.0079978

Overmars, K. P., \&Verburg, P. H. (2005). Analysis of land use drivers at the watershed and household level: Linking two paradigms at the Philippine forest fringe. International Journal of Geographical Information Science, 19(2), 125-152.

http://doi.org/10.1080/13658810410001713380

Pavlek, K., Bišćević, F., Furčić, P., Grđan, A., ...Cvitanović, M. Spatial patterns and drivers of fire occurrence in a Mediterranean environment: a case study of southern Croatia. Danish Journal of Geography, in press. 
Pantić, M. \& Živanović Miljković, J. (2010). Regional differences between rural areas of Serbia in population aging and agricultural activities: case studies of the Inđija and Knjaževac municipalities. Spatium, 22, 29-37.

Pazúr, R., Lieskovský, J., Feranec, J., \& Oahel, J. (2014).Spatial determinants of abandonment of large-scale arable lands and managed grasslands in Slovakia during the periods of post-socialist transition and European Union accession. Applied Geography, 54, 118-128. http://doi.org/10.1016/j.apgeog.2014.07.014

Plieninger, T. (2006). Habitat loss, fragmentation, and alteration - Quantifying the impact of land-use changes on a Spanish dehesa landscape by use of aerial photography and GIS. Landscape Ecology, 21(1), 91-105. http://doi.org/10.1007/s10980-005-8294-1

Prishchepov, A.V., Müller, D., Dubinin, M., Baumann, M. \& Radeloff, V.C. (2013). Determinants of agricultural land abandonment in post-Soviet European Russia. Land Use Policy 30(1), 873-884. http://dx.doi.org/10.1016/j.landusepol.2012.06.011

Prishchepov, A. V., Radeloff, V. C., Baumann, M., Kuemmerle, T., \& Müller, D. (2012). Effects of institutional changes on land use: agricultural land abandonment during the transition from state-command to market-driven economies in post-Soviet Eastern Europe. Environmental Research Letters, 7(2), 024021. http://doi.org/10.1088/1748-9326/7/2/024021

Regos, A., Ninyerola, M., Moré, G., \& Pons, X. (2015). Linking land cover dynamics with driving forces in mountain landscape of the Northwestern Iberian Peninsula. International Journal of Applied Earth Observation and Geoinformation, 38, 1-14. http://doi.org/10.1016/j.jag.2014.11.010

Renwick, A., Jansson, T., Verburg, P. H., Revoredo-Giha, C., Britz, W., Gocht, A., \& McCracken, D. (2013). Policy reform and agricultural land abandonment in the EU. Land Use Policy, 30(1), 446-457. http://doi.org/10.1016/j.landusepol.2012.04.005

Rounsevell, M. D. A. Arneth, A., Brown, D. G., de Noblet-Ducoudre, N., Ellis, E., Finnigan, J., Galvin, K., Grigg, N., Harman, I., Lennox, J., Magliocca, N., Parker, D., O'Neil, B., Verburg, P. H. \& Young, O. (2012). Incorporating human behavior and decision making processes in land use and climate system models. GLP Report No. 7. GLP-IPO, Sao Jose dos Campos.

Rozelle, S. \&Swinnen, J. F. M. (2004). Success and Failure of Reform: Insights from the Transition of Agriculture. Journal of Economic Literature, 42(2), 404-456. http://doi.org/10.1257/0022051041409048

Rutherford,G. N., Bebi'P., Edwards'P. J. \& Zimmermann'N. E. (2008).Assessing land-use statistics to model land cover change in a mountainous landscape in the European Alps. Ecological Modelling, 212(3-4), 460-471.

Shucksmith, M.\& Rønningen, K. (2011). The Uplands after neoliberalism? - The the role of the small farm in rural sustainability. Journal of Rural Studies, 27, 275-287. http:// dx.doi.org/10.1016/j.jrurstud.2011.03.003

Silver, W. L., Ostertag, R. \& Lugo, A. E. (2000). The potential for carbon sequestration through reforestation of abandoned tropical agricultural and pasture lands. Restoration Ecology 8(4), 94-407. http://doi. 10.1046/j.1526-100x.2000.80054.x 
Sklenicka, P., Š́mová, P., Hrdinová, K., \& Salek, M. (2014). Changing rural landscapes along the border of Austria and the Czech Republic between 1952 and 2009: Roles of political, socioeconomic and environmental factors. Applied Geography, 47, 89-98.

http://doi.org/10.1016/j.apgeog.2013.12.006

Skokanová, H., Faltan V., \& Havlíček, M. (2016). Driving forces of main landscape change processes from past 200 years in Central Europe - differences between old democratic and post-socialist countries. Ekológia (Bratislava), 35(1), 56-65. http://doi.org/ 10.1515/eko2016-0004

Snyder, K.A. (1996). Agrarian Change and Land-Use Strategies Among Iraqw Farmers in Northern Tanzania. Human Ecology 24,(3), 315-340.

Sorice, M. G., Kreuter, U. P., Wilcox, B. P., \& Fox III, W. E. (2014). Changing landowners, changing ecosystem? Land-ownership motivations as drivers of land management practices. Journal of Environmental Management, 133, 144-152.

http://doi.org/10.1016/j.jenvman.2013.11.029

Spevec, D. (2009). Populacijski potencijal Krapinsko-zagorske županije. Hrvatski geografski glasnik, 71(2), 43-63.

Taff, G., Müller, D., Kuemmerle, T., Ozdeneral, E., \& Walsh, S.J.(2010). Reforestation in Central and Eastern Europe after the breakdown of socialism. In: Nagendra, H., Southworth, J. (Eds.), Reforesting Landscapes: Linking Pattern and Process (pp. 121-147). New York: Springer.

Tasser' E., Walde'J., Tappeiner' U., Teutsch, A. \& Noggler, W. (2007). Land-use changes and natural reforestation in the Eastern Central Alps. Agriculture, Ecosystems \& Environment, $118(1-4), 115-129$.

Todorović, M. \& Drobnjaković, M. (2010). Peripheral rural areas in Serbia - the result of unbalanced regional development. Geographica Timisiensis, 19(2), 207-219.

Topić, J., Ilijanić, Lj., Tvrtković, N. \& Nikolić, T. (2006). Staništa. Priručnik za inventarizaciju, kartiranje i praćenje stanja. Zagreb: Državni zavod za zaštitu prirode Republike Hrvatske.

Václavik, T.,\&Rogan, J. (2009). Identifying Trends in Land Use/Land Cover Changes in the Context of Post-Socialist Transformation in Central Europe: A Case Study of the Greater Olomouc Region, Czech Republic. GIScience \& Remote Sensing, 46(1), 54-76.

Vassilev, K., Pedashenko, H., Nikolov, S. C., Apostolova, I., \&Dengler, J. (2011). Effect of land abandonment on the vegetation of upland semi-natural grasslands in the Western Balkan Mts., Bulgaria. Plant Biosystems - An International Journal Dealing with All Aspects of Plant Biology, 145(3), 654-665. http://doi.org/10.1080/11263504.2011.601337

Vigl, L. E., Schirpke, U., Tasser, E. \& Tappeiner U. (2016). Linking long-term landscape dynamics to the multiple interactions among ecosystem services in the European Alps. Landscape Ecology, 31(9), 1903-1918.

Vodopivec, M. (1994). Apropriability of returns in the Yugoslav firm. Eastern Economic Journal, 20(3), 337-348. 
Voća, N. (2014). Okoliš na dlanu I - 2014. Zagreb: Agencija za zaštitu okoliša.

Vresk, M. (1972). Socijalni ugar i drugi oblici napuštanja agrarne aktivnosti kao posljedica emigracije i socijalnog diferenciranja stanovništva. Geografski glasnik, 33-34(1), 79-89.

Walsh, S. J., Crawford, T. W., Welsh, W. F., \& Crews-Meyer, K. A. (2001). A multiscale analysis of LULC and NDVI variation in Nang Rong district, northeast Thailand.

Agriculture, Ecosystems \& Environment, 85(1-3), 47-64. http://doi.org/10.1016/S01678809(01)00202-X

Wood, C. H., \& Skole, D. L. (1998). Linking Satellite, Census and Survey Data to Study Deforestation in the Brazilian Amazon. In People and Pixels: Linking Remote Sensing and Social Science (pp. 70-93). Washington D.C.: National Academy Press.

Zimmermann, P., Tasser, E., Leitinger, G. \& Tappeiner,, U. (2010). Effects of land-use and land-cover pattern on landscape-scale biodiversity in the European Alps. Agriculture, Ecosystem and Environment 139, 13-22. 